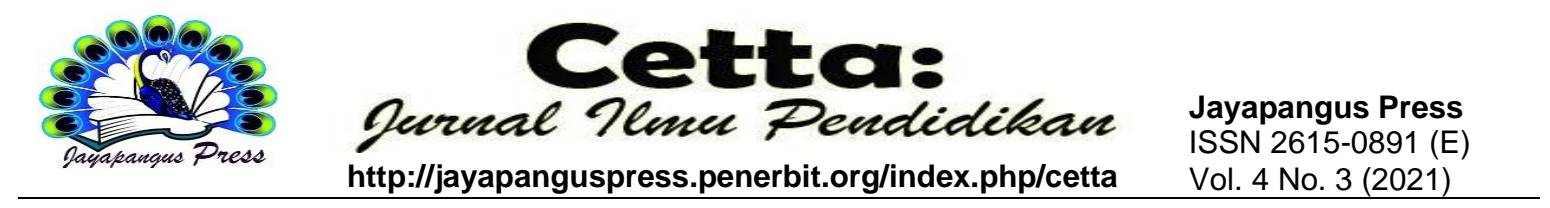

\title{
Implementasi Model Pembelajaran Berbasis Blended Learning Untuk Meningkatkan Kemampuan Keterampilan Berpikir Kritis dan Hasil Belajar Siswa SD
}

\author{
Yunita Anggraeni Sutanti ${ }^{1}$, Suryanti ${ }^{2}$, Zainal Arifin Imam Supardi ${ }^{3}$ \\ ${ }^{123}$ Jurusan Magister Pendidikan Dasar, Universitas Negeri Surabaya, Indonesia \\ 1yunita.19015@mhs.unesa.ac.id
}

\begin{tabular}{l}
\hline Keywords: \\
\hline Blended \\
Learning; \\
Critical Thinking \\
Skills; Learning \\
Outcomes \\
\hline
\end{tabular}

\begin{abstract}
This study aims to apply the blended learning model to improve critical thinking skills and learning outcomes in elementary school students. This research is a research with a quasiexperimental approach (Quasi Experimental). The design used is the Pretest-Posttest Non Equivalent Control Group Design. This research was conducted at SDN Jajartunggal III/452 Surabaya. This study focuses on Class VA and VB. So that the object of development research in this study is the implementation of the blended learning model to improve students' critical thinking skills and learning outcomes. The subjects of this study were 15 students in class VA and 16 students in VB. And the research was conducted for 1 week. In the implementation of the test, the science representation ability test was carried out in class $V A$ and $V B$. The test subject for the science representation ability in the trial class was equivalent to the science representation ability of the research subject. From the results of the analysis, it was found that the average result of the pretest of critical thinking skills in grade 5 A students was 64.33, while the average post-test results of critical thinking skills in grade 5 B students was 86.25 .
\end{abstract}

Kata Kunci:

Blended

Learning;

Keterampilan

Berpikir Kritis;

Hasil Belajar

\begin{abstract}
Abstrak
Penelitian ini bertujuan untuk menerapkan model pembelajaran blended learning untuk meningkatkan kemampuan keterampilan berpikir kritis dan hasil belajar pada siswa SD. Penelitian ini merupakan penelitian dengan pendekatan eksperimen semu (Quasi Experimental). Desain yang digunakan adalah Pretest-Posttest Non Equivalen Control Group Desain. Penelitian ini dilaksanakan di SDN Jajartunggal III/ 452 Surabaya. Penelitian ini berfokus pada Kelas $V_{A}$ dan $V_{B}$. Sehingga objek penelitian pengembangan dalam penelitian ini adalah implementasi model blended learning terhadap peningkatan kemampuan keterampilan berpikir kritis siswa dan hasil belajar. Subjek penelitian ini adalah siswa kelas $V_{A}$
\end{abstract}


sebanyak 15 siswa dan $\mathrm{V}_{\mathrm{B}}$ sebanyak 16 siswa. Serta dilakukan penelitian selama 1 minggu. Pada pelaksanaan ujicoba tes kemampuan representasi IPA dilaksanakan pada kelas V A dan V B. Subjek ujicoba kemampuan representasi IPA kelas uji coba setara dengan kemampuan representasi IPA dari subjek penelitian. Dari hasil analisis diperoleh bahwa Rata-rata hasil Pretest kemampuan keterampilan berpikir kritis pada peserta didik kelas 5 A ialah 64,33, Sedangkan rata-rata hasil posttest kemamapuan keterampilan berpikir kritis pada peserta didik kelas 5 B ialah 86,25

\section{Pendahuluan}

Berfikir kritis dapat dikatakan sebagai proses suatu mental yang sudah teroganisir untuk melakukan analisa dan mengevaluasi suatu informasi, proses mental tersebut bisa berupa cara memperhatikan, mengkategorikan, mengambil kesimpulan ataupun keputusan (Azizah, dkk. 2018; Cahyono, 2017; Amir, 2015). Hasil observasi awal peneliti dilapangan ditemukan bahwa pada saat pembelajaran berlangsung guru ingin menguji tentang sejauh mana kemampuan keterampilan berpikir kritis siswa dengan cara setiap siswa diberi beberapa soal yang berkaitan dengan materi IPA tentang sistem pencernaan pada manusia.

Pada materi sistem pencernaan manusia ini guru menyajikannya dalam bentuk soal cerita atau uraian. Ternyata setelah siswa mengerjakan soal tersebut secara mandiri dari 30 orang siswa hanya $25 \%$ siswa saja yang dapat mengerjakan soal tersebut dengan benar dan disertai penjabaran dari urain soal cerita yang terstruktur. Terdapat 5 siswa saja sedangkan 25 siswa yang lainnya jawabannya belum benar. Dari percobaan soal tersebut dapat dianalisis dan ditarik kesimpulan bahwa dalam mengajarkan keterampilan berpikir kritis pada siswa maka seorang guru harus mengajarkan tahapan-tahapan pemikiran atau tahapan berpikir kritis siswa yaitu dengan cara memahami soal atau permasalahan, melakukan analisis soal, melakukan evaluasi, serta mengambil keputusan atau tindakan dan hasil dari permasalahan tersebut. Sehingga dapat ditemukan hasil dan solusi permasalahan tersebut dengan baik dan benar.

Seorang guru harus mampu merancang dan mengemas pembelajaran sains supaya dapat dinikmati oleh siswa sebagai pembelajaran yang menyenangkan (Saputro dkk, 2021). Di tingkat Sekolah Dasar, guru dapat memanfaatkan pembelajaran sains sebagai wahana untuk menstimulasi keterampilan berfikir kritis yang melibatkan siswa secara langsung melakukan pengalaman sains melalui kegiatan menggunakan berbagai 
indera yang dimiliki (hands on) untuk kemudian mengkonstruk hasil dan temuan mereka menjadi suatu pengetahuan (minds on) (Laelasari \& Andidenjaja, 2018).

Salah satu pembelajaran yang dapat menunjang kegiatan hands on dan minds on tersebut adalah kegiatan praktikum/ kegiatan laboratorium. Pembelajaran berbasis laboratorium memungkinkan siswa untuk mengalami prinsip bioscience pertama (Laelasari \& Andidenjaja, 2018. Dengan demikian penting untuk mengeksplorasi pendekatan alternatif untuk memaksimalkan potensi belajar dalam praktek dasar siswa aktif. Menurut Sofiyah (2021) \& Agustina (2018) menuliskan bahwa pengalamam laboratorium memiliki peran sentral dalam pendidikan sains. Banyak manfaat yang diperoleh siswa ketika mereka terlibat dalam kegiatan siswa. Hal tersebut juga berkaitan dengan hakikat sains sebagai suatu produk, proses dan sikap ilmiah. Sains sebagai suatu produk menunjukkan bahwa di dalam sains terdapat sejumlah fakta, hukum, prinsip, dan teori-teori yang kebenarannya sudah dapat diterima (Ali, dkk. 2013; Pujani \& Slamet, 2020). Sementara sains sebagai proses mengandung arti bahwa diperlukan suatu proses tertentu yang harus dilakukan untuk memperoleh suatu pengetahuan. Proses ini akan melibatkan siswa untuk aktif menemukan pengetahuan (process objectives). Pengetahuan yang dimaksud bukan sekedar pengetahuan deklaratif (pengetahuan tentang apa sesuatu itu), melainkan juga pengetahuan prosedural (pengetahuan tentang bagaimana melakukan sesuatu).

Namun, disaat pandemik saat ini beberapa kendala dihadapi, mulai dari larangan untuk melakukan sekolah tatap muka disekolah dan pembatasan aktivitas pendidikan disekolah. Sehingga memungkin kan guru untuk mencari alternative untuk mengantisipasi hal tersebut. Selain itu, pemilihan model pembelajaran juga mempengaruhi keterlaksaan pembelajaran. Salah satu model pembelajaran yang kemungkinan besar dapat memberikan peluang yang cukup signifikan adalah model pembelajaran blended learning.

Secara etimologi istilah blended learning terdiri dari dua kata yaitu blended yang berarti campuran dan learning yang berarti pembelajaran (Indra, 2010; Sukoco, 2017). Dengan demikian blended learning mengandung makna pola pembelajaran yang mengandung unsur pencampuran atau penggabungan antara satu pola dengan pola yang lainnya dalam pembelajaran (Widiara, 2018; Wicaksono \& Rachmadyanti, 2017). Mosa (2006) menyampaikan bahwa yang dicampurkan dalam blended learning yaitu dua unsur utama, yakni pembelajaran di kelas (classroom lesson) dengan online learning. Blended 
learning yaitu model pembelajaran yang memadukan pertemuan tatap muka dengan materi online secara harmonis (Sulisworo, dkk. 2016; Frafika, dkk. 2018). Perpaduan antara pembelajaran konvensional di mana pendidik dan peserta didik bertemu langsung dengan pembelajaran secara online yang dapat diakses kapan saja dan di mana saja (Hikmatiar, dkk. 2020). Adapun bentuk lain dari blended learning adalah pertemuan virtual antara pendidik dengan peserta didik. Dimana antara pendidik dan peserta didik mungkin saja berada di dua tempat yang berbeda, namun bisa saling memberi feedback, bertanya, atau menjawab dan semuanya dilakukan secara real time.

Blended learning merupakan solusi dari kelemahan-kelemahan dari pembelajaran online karena menggabungkan online, offline dan pembelajaran tatap muka (Sulisworo, dkk. 2016; Ardianti, dkk. 2019). Pembelajaran online terdiri dari media yang dilengakapi dengan alat pengontrol yang digunakan oleh pengguna (user) sehingga pengguna ((user) dapat mengakses adapun media oflline tidak dilengkapi dengan alat pengontrol yang dapat digunakan oleh pengguna ((user)yang tidak perlu terkoneksi dengan jaringan internet misalnya materi bentuk tutorial dalam bentuk CD atau media yang sudah dibuat melalui aplikasi yang bisa digunakan oleh siswa tanpa terkoneksi pada jaringan internet (Arnesti \& Hamid, 2015; Abdullah, 2018).

Berbagai penelitian telah dilakukan, satu diantaranya adalah Nurhadi (2020) bahwa banyak guru tertarik dengan pembelajaran online. Namun Bates (2009) menambahkan begitu pula sebaliknya pembelajaran online sangat butuh pembelajaran langsung unutk memberikan feedback antara guru dengan siswanya. Pembelajaran dengan pengembangan teknologi dengan kombinasi pembelajaran tatap muka maka dapat dihasilkan suatu pembelajaran yang lebih efektif dan efisien. Pembelajaran ini seimbang antara tatap muka dengan pembelajaran online yaitu dengan menggunakan multimedia yang dimuat dalam komputer, handphone, konfeksi video dan media tekonologi yang lainnya (Firman \& Rahayu, 2020; Anggrawan, 2019).

Tenaga pengajar dengan siswa dapat melakukan komunikasi sekalipun dengan jarak dan tempat yang berbeda dan juga siswa dapat dilengkapi dengan pembelajaran tatap muka yang memungkingkan terdapat permasalahan dalam materi pembelajaran online. Selain itu, studi yang dilakukan oleh Fayanto, dkk (2019) membuktikan bahwa pembelajaran berbasis blended learning berbasis leaning management system dapan membantu meningkatkan minat siswa dalam belajar. 
Oleh karena itu, berdasarkan uraian yang telah dipaparkan peneliti tertarik untuk mencoba mengembangkan sebuah pembelajaran berbasis blended learning untuk meningkatkan keterampilan berpikir kritis, khusunya pada siswa sekolah dasar. Kajian ini diharapkan menjadi salah satu sumber belajar pada siswa sekolah dasar.

\section{Metode}

Penelitian ini merupakan penelitian kuantitatif dengan pendekatan quasi Experimental dengan pretest-posttest non equivalen control group design. Penelitian ini menggunakan dua variabel, yaitu variabel eksperimen dan variabel terikat. Adapun sebagai variabel eksperimen adalah variabel perlakuan untuk kelas eksperimen, yaitu model pembelajaran langsung blended learning yang berbasis LMS, dan variabel perlakuan untuk kelas kontrol yang digunakan sebagai pembanding yaitu model pembelajaran secara langsung atau tatap muka. Sedangkan variabel terikatnya adalah keterampilan berpikir kritis dan variabel moderatornya adalah materi IPA sistem pencernaan manusia. Penelitian ini dilaksanakan di SDN Jajartunggal III/ 452 Surabaya. Penelitian ini berfokus pada Kelas $\mathrm{V}_{\mathrm{A}}$ dan $\mathrm{V}_{\mathrm{B}}$. subjek penelitian ini adalah siswa kelas $\mathrm{V}_{\mathrm{A}}$ sebanyak 15 siswa dan $\mathrm{V}_{\mathrm{B}}$ sebanyak 16 siswa.

Prosedur penelitian terdiri dari preliminary design, eksperiment dan retrospective analysis. Sedangkan, instrumen yang dibutuhkan pada penelitian ini terdapat 4 instrumen yaitu berupa lembar penilaian perangkat pembelajaran blended learning, lembar pengamatan aktivitas kemampuan siswa. Selain itu, metode pengumpulan data terdiriu dari lembar tes, observasi dan angket. Teknik analisis data yang digunakan menggunakan analisis deksriptif dan analisis inferensial (uji-T).

\section{Hasil dan Pembahasan}

Hasil kuisioner atau angket, serta hasil wawancara peserta didik terhadap pembelajaran IPA dengan materi terkait sistem pencernaan makanan pada manusia dengan menggunakan model pembelajaran blended learning berbantu Aplikasi Edmodo dan WhatsApp serta metode cermah secara aktif. Aktivitas pembelajaran siswa selama proses pembelajaran terdiri dari Pada pertemuan pertama untuk kelas kontrol di kelas 5 B pada jam pelajaran ke-5 sampai ke-8 dengan jumlah siswa sebanyak 16 orang peserta didik. Untuk kegiatan yang dilakukan sama dengan kegiatan yang dilakukan pada pertemuan pertama kelas eksperimen di kelas $5 \mathrm{~A}$, yaitu dilakukan pembelajaran secara 
luring atau tatap muka secara langsung dengan para peserta didik serta memberikan materi dan soal-soal serta pembahasan secara langsung.

Pada pertemuan kedua, kelas eksperimen atau pada kelas 5 A. Pada penelitian ini peneliti menggunakan metode pembelajaran secara daring atau pembelajaran secara online dengan menggunakan media Aplikasi Zoom sebagai tempat atau platform pada saat proses pembelajaran secadra daring berlangsung. Pada pembelajaran secara daring atau online tersebut para peserta didik diminta untuk membuat atau bergabung ke Aplikasi WhatsApp dan Edmodo yang proses pembuatan akun untuk bergabung ke Aplikasi tersebut dan beserta sistematika penggunaan telah dibantu atau dibimbing oleh peneliti. Sedangkan para peserta didik tinggal memakai dan mengoperasionalkan Aplikasi tersebut. Yang berfungsi dan bertujuan untuk digunakan pada saat proses pembelajaran dan penyampaian materi pembelajran berlangsung. Lalu, selain peneliti memberikan materi dan tugas-tugas secara individual, peneliti juga memberikan tugas dan soal-soal secara berkelompok dengan cara diskusi secara kelompok kepada para peserta didik yang berkaitan dengan materi yang dipelajari tentang system pencernaan makanan pada manusia. Pada saat proses pembelajaran berlangsung para peserta didik sangat semangat dan antusias sekali dalam menyimak dan mengerjakan soal-soal yang disampaikan serta diberikan oleh peneliti.

Pada pertemuan ketiga, pada kelas kontrol di kelas 5 B dilakukan pembelajaran dengan kelas eksperimen atau kelas 5A. Pada pertemuan ini peneliti menggunakan model pembelajaran secara daring dengan menggunakan media atau platform pada Aplikasi Zoom sebagai media tempat berlangsung nya proses kegiatan belajar mengajar dan pembelajaran yang membahas tentang materi pembelajaran terkait dengan sjstem pencernaan makanan pada manusia. Pada proses pembelajaran yang dilakukan secara Daring atau online tersebut peneliti menggunakan bantuan media power point dan video animasi interaktif untuk membantu peneliti dalam penyampaian materi pembelajaran tentang system pencernaan makanan pada manusia. Agar para peserta didik dapat memahami materi yang disampaikan oleh peneliti secara baik dan benar. Pada saat pengerjaan soal-soal dan pembahasan baik itu pada soal pretest maupun pada soal postest para peserta didik terlihat sangat aktif dan bersemangat dalam pengerjaan soal-soal dan pembahasan tersebut. Setelah semua kegiatan proses pembelajaran serta semua penelitian selesai dilaksanakan peneliti melakukan foto-foto bersama dan pengambilan video serta 
proses pengambilan dokumentasi yang digunakan sebagai bukti autentik dan pelengkap selama proses penelitian dan pembelajaran berlangsung dengan baik.

Selanutnya, hasil analisis diperoleh dalam bentuk dua bentuk kategori yang dari segi keterampilan berpikir kritis dan hasil belajar. Dari segi keterampilan berpikir kritis hasil analisis disajikan pada Tabel 1.

Tabel 1. Hasil Peningkatan Kemampuan Keterampilan Berpikir Kritis dan Hasil Belajar

\begin{tabular}{llcc}
\hline \multirow{2}{*}{ Kelas } & \multirow{2}{*}{ Perlakuan } & \multicolumn{2}{c}{ Rata-Rata } \\
\cline { 3 - 4 } & & Keterampilan Berpikir kritis & Hasil Belajar \\
\hline \multirow{2}{*}{ 5 A } & Pre test & 64,33 & 68,33 \\
& Post tets & 74,33 & 77,66 \\
\hline \multirow{2}{*}{ 5 B } & Pre test & 75,31 & 76,25 \\
& Post tets & 86,25 & 87,5 \\
\hline
\end{tabular}

Berdasarkan Tabel 1 terlihat bahwa hasil Pretest kemampuan keterampilan berpikir kritis pada peserta didik kelas 5 A ialah 64,33, Menurut klasifikasi pada kemampuan keterampilan berpikir kritis pada tabel hasil nilai tersebut rata-rata hasilnya ternyata pretest tersebut masuk dalam klasifikasi sangat rendah dari skor perbandingan nilai maksimal 100. Sedangkan pada tabel rata-rata hasil pretest kemamapuan keterampilan berpikir kritis pada peserta didik kelas 5 B ialah 75,31.

Menurut klasifikasi pada kemampuan keterampilan berpikir kritis pada tabel hasil nilai tersebut rata-rata hasilnya ternyata pretest tersebut masuk dalam klasifikasi sangat rendah dari skor perbandingan nilai maksimal 100. rata-rata hasil Posttest kemampuan keterampilan berpikir kritis pada peserta didik kelas 5 A ialah 68,33, Menurut klasifikasi pada kemampuan keterampilan berpikir kritis pada tabel hasil nilai tersebut rata-rata hasilnya ternyata pretest tersebut masuk dalam klasifikasi sangat rendah dari skor perbandingan nilai maksimal 100. Sedangkan pada tabel rata-rata hasil posttest kemamapuan keterampilan berpikir kritis pada peserta didik kelas 5 B ialah 86,25 berada pada kategori tinggi. Hasil ini sejalan dengan studi yang dilakukan oleh Sinaga \& Simanjuntak (2020) bahwa hasil tes kemampuan berpikir kritis N-gain menunjukkan peningkatan berpikir kritis kelas eksperimen $71 \%$ dan kelas kontrol 38\%. Sedangkan Suana, dkk (2020) berkata siswa memiliki minat yang tinggi, kemudahan belajar, dan memiliki manfaat dalam meningkatkan pengetahuannya ketika diterampkan pembelajaran berbasis blended learning.

Selain itu, dari tabel rata-rata hasil pretest hasil belajar pada peserta didik kelas 5 A ialah 68,33, Menurut klasifikasi pada kemampuan hasil belajar pada tabel hasil nilai 
tersebut rata-rata hasilnya ternyata pretest tersebut masuk dalam klasifikasi sangat rendah dari skor perbandingan nilai maksimal 100. Sedangkan pada tabel rata-rata hasil pretest hasil belajar pada peserta didik kelas $5 \mathrm{~B}$ ialah 76,25. Rata-rata hasil posttest hasil belajar pada peserta didik kelas 5 A ialah 77,66, Menurut klasifikasi pada kemampuan keterampilan berpikir kritis pada tabel hasil nilai tersebut rata-rata hasilnya ternyata pretest tersebut masuk dalam klasifikasi sangat rendah dari skor perbandingan nilai maksimal 100. Sedangkan pada tabel rata-rata hasil posttest hasil belajar pada peserta didik kelas 5 B ialah 87,5 berada pada kategori tinggi. Badrus \& Arifin (2021) dalam studinya menuliskan bahwa dengan menggunakan model blended learning berpengaruh terhadap hasil belajar komprehensi siswa. Sejalan dengan hal tersebut, Utami (2020); Vonti \& Rahma (2019) melaporkan bahwa model blended learning lebih berkontribusi terhadap prestasi belajar siswa dan literasi digital siswa. Sedangkan, Fauzia, dkk (2021) melaporkan blanded learning dapat meningkatkan hasil belajar dengan total skor 0.4810.

Tabel 2. Hasil Statistik Uji-T pada Aspek Keterampilan Berpikir Kritis dan Hasil

Belajar

\begin{tabular}{ll}
\hline Independent Tes & Uji-T $\left(\mathrm{t}_{\text {hitung }}\right)$ \\
\hline Keterampilan berpikir kritis & 0.000 \\
Hasil belajar & 0.000 \\
\hline
\end{tabular}

Berdasarkan uji-T pada Tabel 2 proses kemampuan keterampilan berpikir kritis peserta didik pada kelas 5 A maupun kelas 5 B. Hasil T-Test kelompok independent pada kelas 5A \& 5B nilai (2-tailed $=0.000)$ lebih kecil dari level signifikan $(a=0,05)$ sehingga hasilnya adalah terdapat perbedaan yang signifikan. Sehingga, hasil uji-T pada Tabel 1 menunjukkan bahwa kemampuan keterampilan berpikir kritis pada peserta didik pada siswa kelas 5 A dan siswa kelas 5 B pada materi terkait sistem pencernaan makanan pada manusia hasilnya ada perbedaan. Berdasarkan hasil rata-rata nilai pretest kemampuan keterampilan berpikir kritis Pada siswa kelas 5 A yaitu 74,33 dan pada siswa kelas B yaitu 77,66. Hasil ini sejalan dengan studi yang dilakukan oleh Hasanah \& Malik (2020) bahwa (1) penerapan model blended learning efektif meningkatkan keterampilan berpikir kritis; (2) penggunaan model blended learning efektif meningkatkan keterampilan komunikasi siswa dan (3) berdasarkan uji independent sample uji-T, keterampilan berpikir kritis dan keterampilan komunikasi siswa kelas eksperimen memiliki perbedaan yang signifikan dengan kelas kontrol. Hal ini didukung dari studi Prafitasari, dkk (2021) bahwa 
penggunaan blended learning dapat meningkatkan kemampuan berpikir kritis dalam pembelajaran IPA dengan pembelajaran sistem blended learning menjadi lebih efektif

Sedangkan, dari hasil belajar menunjukkan bahwa kemampuan hasil belajar pada peserta didik pada siswa kelas 5A dan siswa kelas 5B pada materi terkait sistem pencernaan makanan pada manusia hasilnya terdapat perbedaan dengan nilai uji-T (0.000). Berdasarkan hasil rata-rata nilai Pretest kemampuan keterampilan berpikir kritis Pada siswa kelas 5 A yaitu 86,25 dan pada siswa kelas B yaitu 87.5. Hariadi, dkk (2019) menuliskan bahwa pembelajaran hybrid management IPA untuk meningkatkan hasil belajar siswa ditunjukkan oleh peningkatan hasil belajar siswa yang signifikan secara statistik pada $=5 \%$. Sedangkan, Irawan, dkk (2017) melaporkan bahwa blended learning terbukti meningkatkan hasil belajar dan keterampilan siswa SMK di kelas dibandingkan siswa yang menggunakan tatap muka

Dari hasil pengamatan dapat diketahui bahwa pada aktivitas para peserta didik selama proses pembelajaran berlangsung dengan menggunakan model blended learning, siswa lebih banyak untuk mengerjakan tugas dan soal secara kelompok serta diskusi bersama. Namun, pada pertemuan pertama para peserta didik cenderung masih banyak bergantung pada penjelasan guru pada saat proses pembelajaran berlangsung karena para siswa belum bias beradaptasi dengan model pembelajaran blended learning terutama pada pembelajaran secara daring atau online. Ada salah satu hal yang perlu digaris bawahi yaitu bahwa pada kegiatan pembelajaran menggunakan model blended learning ternyata dapat lebih mengaktifkan para peserta didik dan kegiatan pembelajaran menjadi lebih aktif, kreatif, interaktif dan lebih menyenangkan serta tidak monoton serta dapat meningkatkan hasil pembelajaran para peserta didik menjadi lebih baik. Istia'nah (2017) menuliskan dalam kajiannya bahwa blended learning memberikan pengalaman belajar yang efektif dan efisien dengan menggabungkan lingkungan belajar yang sesuai dengan siswa.

Hal ini dikarenakan selama proses pembelajran blended learning tersebut para peserta didik diminta untuk saling berdiskusi antar kelompok secara bersama-sama serta dengan cara bekerja sama dalam pembelajaran. Serta para peserta didik diminta untuk berdiskusi, mendengarkan penjelasan dan pendapat dari teman yang lainnya, dan menyampaikan ide-ide dengan menggunakn bahasa sendiri. Suma, dkk (2020) mengemukakan bahwa dengan menggunakan blended learning pembelajaran siswa lebih terarah dan terdapat interaksi langsung dengan pengajar dalam kegiatan pembelajaran 
tatap muka. Hal ini juga didukung dengan pertanyaan respon siswa sendiri dalam angket respon terhadap pembelajran dengan menggunakan model pembelajaran blended learning dan pencapaian peningkatan hasil kemampuan keterampilan berpikir kritis siswa serta dari pencapaian hasil belajar para peserta didik baik kegiatan secara individu maupun hasil kegiatan secara diskusi kelompok.

\section{Kesimpulan}

Dari hasil analisis dapat disimpulkan bahwa penerapan model pembelajaran blended learning mampu mempunyai pengaruh yang cukup signifikan terhadap kemampuan keterampilan berpikir kritis siswa dan kemampuan hasil belajar siswa SD. Dengan rata hasil Pretest kemampuan keterampilan berpikir kritis pada peserta didik kelas 5 A ialah 64,33, Sedangkan rata-rata hasil posttest kemamapuan keterampilan berpikir kritis pada peserta didik kelas 5 B ialah 86,25.

\section{Daftar Pustaka}

Abdullah, W. (2018). Model blended learning dalam meningkatkan efektifitas pembelajaran. Fikrotuna, 7(1), 855-866.

Agustina, M. (2018). Peran Laboratorium Ilmu Pengetahuan Alam (IPA) Dalam Pembelajaran IPA Madrasah Ibtidaiyah (MI)/Sekolah Dasar (SD). AT-TA'DIB: Jurnal Ilmiah Prodi Pendidikan Agama Islam, 1-10.

Ali, L. U., Suastra, I. W., \& Sudiatmika, A. A. I. A. R. (2013). Pengelolaan pembelajaran IPA ditinjau dari hakikat sains pada SMP di Kabupaten Lombok Timur. Jurnal Pendidikan Dan Pembelajaran IPA Indonesia, 3(1).

Amir, M. F. (2015). Proses berpikir kritis siswa sekolah dasar dalam memecahkan masalah berbentuk soal cerita matematika berdasarkan gaya belajar. Jurnal Math Educator Nusantara: Wahana Publikasi Karya Tulis Ilmiah di Bidang Pendidikan Matematika, 1(2).

Anggrawan, A. (2019). Analisis deskriptif hasil belajar pembelajaran tatap muka dan pembelajaran online menurut gaya belajar mahasiswa. MATRIK: Jurnal Manajemen, Teknik Informatika Dan Rekayasa Komputer, 339-346.

Ardianti, S., Sulisworo, D., \& Pramudya, Y. (2019). Efektivitas Blended Learning Berbasis Pendekatan STEM Education Berbantuan Schoology Untuk Meningkatkan Critical Thinking Skill Pada Materi Fluida Dinamik. In Prosiding Seminar Nasional Pendidikan Kaluni (Vol. 2, No. 0, pp. 240-246).

Arnesti, N., \& Hamid, A. (2015). Penggunaan media pembelajaran online-offline dan komunikasi interpersonal terhadap hasil belajar bahasa inggris. Jurnal Teknologi Informasi \& Komunikasi Dalam Pendidikan, 2(1). 
Azizah, M., Sulianto, J., \& Cintang, N. (2018). Analisis keterampilan berpikir kritis Siswa sekolah dasar pada pembelajaran matematika kurikulum 2013. Jurnal Penelitian Pendidikan, 35(1), 61-70.

Badrus, B., \& Arifin, Z. (2021). The Effect of The Blended Learning Model on The Improvement of Student Learning Outcomes. Nazhruna: Jurnal Pendidikan Islam, 4(1), 108-116.

Bates, T. (2009). Managerial perspectives on e-leaning. E-learning, 14-27.

Cahyono, B. (2017). Analisis ketrampilan berfikir kritis dalam memecahkan masalah ditinjau perbedaan gender. AKSIOMA: Jurnal Matematika dan Pendidikan Matematika, 8(1), 50-64.

Fauziah, D. Z., Basori, B., \& Maryono, D. The Influence of LMS-Based Blended Learning Models on Learning Motivation and Learning Outcomes in Network Infrastructure Administration. Journal of Informatics and Vocational Education, 4(1).

Fayanto, S., Kawuri, M. Y. R. T., Jufriansyah, A., Setiamukti, D. D., \& Sulisworo, D. (2019). Implementation E-Learning based moodle on physics learning in senior high school. Indonesian Journal of Science and Education, 3(2), 93-102.

Firman, F., \& Rahayu, S. (2020). Pembelajaran online di tengah pandemi covid19. Indonesian Journal of Educational Science (IJES), 2(2), 81-89.

Frafika Sari, I., Rahayu, A., Apriliandari, D. I., \& Dwi, S. (2018). Blended Learning: Improving Student's Motivation in English Teaching Learning Process. International Journal of Languages' Education and Teaching, 6(1), 163170.

Hariadi, B., Sunarto, M. J., \& Sudarmaningtyas, P. (2019). Hybrid learning by using brilian applications as one of the learning alternatives to improve learning outcomes in college. International Journal of Emerging Technologies in Learning, 14(10), 34-45.

Hasanah, H., \& Malik, M. N. (2020). Blended learning in improving students' critical thinking and communication skills at University. Cypriot Journal of Educational Sciences, 15(5), 1295-1306.

Hikmatiar, H., Sulisworo, D., \& Wahyuni, M. E. (2020). Pemanfaatan Learning Manegement System Berbasis Google Classroom Dalam Pembelajaran. Jurnal Pendidikan Fisika, 8(1), 78-86.

Indra, N. (2010). Pembelajaran Hibrida sebagai Strategi Model Pembelajaran Masa Depan. Masyarakat Telematika Dan Informasi: Jurnal Penelitian Teknologi Informasi dan Komunikasi, 1(2), 119-130.

Irawan, V. T., Sutadji, E., \& Widiyanti. (2017). Blended learning based on schoology: Effort of improvement learning outcome and practicum chance in vocational high school. Cogent Education, 4(1), 1282031. 
Isti'anah, A. (2017). The effect of blended learning to the students' achievement in grammar class. IJEE (Indonesian Journal of English Education), 4(1), 16-30.

Laelasari, I., \& Adisendjaja, Y. H. (2018). Mengeksplorasi kemampuan berpikir kritis dan rasa ingin tahu siswa melalui kegiatan laboratorium inquiry sederhana. Thabiea: Journal of Natural Science Teaching, 1(1), 14-19.

Mosa, E. (2006). A Blended Learning Model Current Development In Technology. Asisted Education 6 (4), 1744, 1749, 2006.

Nurhadi, N. (2020). Blended Learning dan Aplikasinya di Era New Normal Pandemi Covid 19. AGRIEKSTENSIA: Jurnal Penelitian Terapan Bidang Pertanian, 19(2), 120-128.

Prafitasari, F., Sukarno, S., \& Muzzazinah, M. (2021). Integration of Critical Thinking Skill in Science Learning Using Blended Learning System in Elementary School. International Journal of Elementary Education, 5(3).

Pujani, N. M., \& Selamet, K. (2020). Pengelolaan Laboratorium Ilmu Pengetahuan Alam (Ipa) Smp Negeri 2 Singaraja. Jurnal Pendidikan dan Pembelajaran Sains Indonesia (JPPSI), 3(2), 118-129.

Saputro, A. N. C., Suhelayanti, S., Chabibah, N., Bermuli, J. E., Sinaga, K., Fauzi, A.,\& Fayanto, S. (2021). Pembelajaran Sains. Medan: Yayasan Kita Menulis.

Sinaga, J. T., \& Simanjuntak, M. P. (2020). The Effect Of Blended Learning Model To Critical Thinking Skill Students In Senior High School. Jurnal Inovasi Pembelajaran Fisika (INPAFI), 8(4), 13-19.

Sofiyah, S. (2021). Upaya Peningkatan Kualitas Hasil Belajar Mata Pelajaran Ilmu Pengetahuan Alam Siswa Kelas VIII MTsN 1 Tuban Melalui Kegiatan Laboratorium. Inovasi-Jurnal Diklat Keagamaan, 15(1), 66-77.

Suana, W., Ningsih, W. S. A., Maharta, N., \& Putri, N. M. A. A. (2020, June). The effect of blended learning setting on students' critical thinking skills in physics. In Journal of Physics: Conference Series (Vol. 1572, No. 1, p. 012073). IOP Publishing.

Sukoco, P. C. (2017, November). Blended Learning Dalam Pembelajaran. In Seminar Nasional Pendidikan Olahraga (Vol. 1, No. 1, pp. 339-346).

Sulisworo, D., Agustin, S. P., \& Sudarmiyati, E. (2016). Cooperative-blended learning using Moodle as an open source learning platform. International Journal of Technology Enhanced Learning, 8(2), 187-198.

Sulisworo, D., Rahayu, T., \& Akhsan, R. N. (2016). The students' academic writing skill after implementing blended learning using Facebook. Інформаційні технологіï $i$ засоби навчання, (56, вип. 6), 176-191.

Suma, K., Suwindra, I. N. P., \& Sujanem, R. (2020). The Effectiveness of Blended Learning in Increasing Prospective Physics Teacher Students' Learning Motivation and Problem-Solving Ability. JPI (Jurnal Pendidikan Indonesia), 9(3), 436-445.

Utami, I. S. (2018). The effect of blended learning model on senior high school students' achievement. In SHS Web of Conferences (Vol. 42, p. 00027). EDP Sciences. 
Vonti, L. H., \& Rahmah, M. (2019). The Use Of Hybrid/Blended Learning In Understanding Of English Structure Subject To Improve Students'achievement And Their Digital Literacy. Jhss (Journal of Humanities And Social Studies), 3(2), 99-102.

Wicaksono, V. D., \& Rachmadyanti, P. (2017). Pembelajaran blended learning melalui google classroom di sekolah dasar.

Widiara, I. K. (2018). Blended learning sebagai alternatif pembelajaran di era digital. Purwadita: Jurnal Agama dan Budaya, 2(2), 50-56. 